\title{
Health-Saving Technologies in the Context of Globalization
}

\author{
Varynskyi Vladyslav
}

\begin{abstract}
The article raises problems of the value of human life and health in the context of globalization. Health is defined as the starting point for human self-realization and is viewed from the point of view of the philosophy of prevention and protection. The new paradigm of axiological perception of a person in the unity of his physical characteristics and spiritual coordinates represents the problems of human health, quality of life, opportunities and life expectancy as priorities for social development and public policy, which determines the relevance of theoretical significance and practical development of this problem, the need for comprehensive research in medicine. philosophy, sociology, law and education; improvement of methodological and organizational approaches to the preservation of health, its formation and development.

The decline of public health in modern realities necessitated the study of effective mechanisms to increase its level.

This article has identified and analyzed technologies that preserve human health. Attention is focused on a healthy lifestyle and motor activity. Provides statistics related to human health and physical activity. Lack of physical activity is considered an important factor in causing noncommunicable diseases.

A large role in the formation of a positive attitude to their health is played by international projects aimed at solving the problem of insufficient physical activity. The article discusses the most interesting technologies aimed at overcoming physical inactivity. Revealed their positive dynamics. Effective Ukrainian strategies are also emphasized.
\end{abstract}

The study showed that health-saving technologies are prevention and protection technologies that ensure the psychophysiological safety of a person. They embody strategies aimed at preserving and promoting health and developing a healthy lifestyle. Presented in medical, educational, political and humanitarian discourses. Are a condition for the development and self-regulation of personality.

These studies have shown that the formation of requirements for maintaining a healthy lifestyle is an important social task of medicine, philosophy, sociology, pedagogy and other branches of human knowledge, each individually perceived person and the whole society. In this regard, an integrated approach to its solution.

Keywords : globalization, axiological parameters of health, philosophy of prevention and protection, health-saving technologies, physical activity.

\section{INTRODUCTION}

The vital activity of modern man occurs in a period of dynamic changes associated with the processes of globalization and integration. These transformations are particularly relevant for Ukrainian society. Restarting the development of the Ukrainian state in the format of introducing European norms of life marked new potencies of key values.

\footnotetext{
Revised Manuscript Received on November 15, 2019

* Correspondence Author

Varynskyi Vladyslav Candidate of Political Sciences, lecturer, Odessa

State University of Internal Affairs, Uspenska st. 1, Odessa, Ukraine,

65014
}

The man of value is the dominant of a democratic society. In the global anthropological paradigm, man is defined by the standard of axiology. All surrounding objects are considered according to their role and importance for his life activity, involvement in the processes of development of the human person. On the basis of the value orientations of the individual, various aspects of human life are formed, a system of interconnected evaluative representations reflecting its legal, religious, moral norms, a strategy of personal self-sufficiency is established.

The implementation of the resources of the individual, in turn, is closely related to the state of human health, his performance. Axiology of health is often represented by scientists in the form of a pyramid, on top of which is the highest value - human life [8]. According to a survey of households in Ukraine, conducted by the State Statistics Service of Ukraine in 2017 and published on the Khvylya information and analytical website, "the main value of Ukrainians (for $75.9 \%$ of respondents) is health. The second place among value priorities with a fairly large gap is occupied by family relations and children (18.8\%). Finally, the total remaining amount (slightly more than $5 \%$ ) is wealth values $(2.3 \%)$, confidence in the future $(1.4 \%)$, work, career, education (1.2\%), social justice (0.4\%)" [5].

The subordinate values in this hierarchy are those that fill life with meaning, make it full-fledged, give us the strength and incentive to live. Thus, "health is a humanitarian value in and of itself; besides, it is a necessary condition for the possibility of realizing values of a higher order" [2].

The new paradigm of axiological perception of a person in the unity of its physical characteristics and spiritual coordinates represents global problems of a person's health, quality of life, opportunities and longevity as priority tasks of social development and state policy, which determines the relevance of the theoretical and practical development of this problem, the need for integral research in medicine, philosophy, sociology, law and education; improvement of methodological and organizational approaches to the preservation of health, its formation and development. The importance of integral health research methods is confirmed in the Health Status Report in Europe, 2018, made by the World Health Organization. Prioritizing an integrated approach based on the use of mixed methods allows for an analysis of health trends, taking into account societal and cultural factors affecting human health and well-being, focus on the core values underlying Health 2020, such as ensuring resilience at all stages of life [16].

In modern living conditions, a decrease in the health of the population is recorded. This circumstance causes concern not only of international society, but also of scientists [4]. 
The global environment, the transformation of the biosphere, man-made hazards, lifestyles pose potential threats to human health, and therefore at the level of government policy research is being encouraged to develop effective mechanisms to preserve the health of the nation and every person.

The health phenomenon is not a new object of research. A large number of works are devoted to his analysis. Due to the fact that the concept of health was developed by many scientists in various disciplines, there are still different interpretations of this concept. This is quite understandable. Each industry has its own, distinct from other goal, according to which it determines the meaning of the concept. We focus on the Charter of the World Health Organization, which states that "health is a state of complete physical, mental and social well-being, and not only the absence of disease and physical defects" [14]. This definition emphasizes the triune integrity of the concept. Physical health is considered as the current state of the functional capabilities of organs and body systems. Mental health is presented in terms of the state of mental well-being and the absence of mental deviations, which is characterized by adequate regulation of behavior in the environment. And social health is represented at the level of the system of values, attitudes and motives of behavior in the social environment [13]. A common point of intersection of the physical, moral and social well-being of a person are the value coordinates of the individual, society and governments.

In our work, we will consider the phenomenon of health in the complex of its components as a category in human life from the standpoint of the philosophy of prevention and protection. The philosophy of prevention and protection, primarily aimed at creating technologies that save health. It appeals to the individual, society and governments to improve the quality of life and is integral, which corresponds to the priority of noncommunicable disease prevention and control in a global, regional and national perspective through increased international cooperation and advocacy [15].

\section{MATERIALS AND METHODS}

\subsection{Research material}

The study was based on health and technology statistics aimed at preserving human health.

As the basic methods were used analysis, comparison and survey.

\subsection{Methodological base}

The methodological base of the research is focused on the new research methodology, which is based on interdisciplinary principles that are declared in modern science, monitoring, general scientific methods, and has an integral character. An integrated approach to scientific research is based on the general idea of a holistic, comprehensive, objective presentation of the object of study.

\section{RESULTS}

\subsection{Risks in the context of globalization}

Health strategies are a priority for people and for politics. Their number is quite large. We will focus on those that can be used in the format of a philosophy of prevention and protection.
In the context of globalization, people are constantly faced with certain risks. Our field of research did not include economic or political risks as risks of indirect effects on human health. Among the risks that pose a direct threat to human health, there are

1) unforeseen risks in the form of man-made disasters, all sorts of accidents, natural disasters; 2) environmental risks associated with human activities (we perceive them as boomerang risks); 3) professional risk associated with production; 4) risks associated with lack of competence in matters of their own health.

Prevention of the first type of risk takes place, but not always depends on the person. It aims to minimize damage to human life.

Prevention of the second type of risk, by contrast, is determined by human activity, the relationship of man and the environment. It is included in a number of global problems of mankind and is solved on a local, regional and global scale. Its goal is to prevent an ecological catastrophe and preserve the quality of human life.

Prevention of the third type of risk is associated with the optimization of work and life and is regulated in the workplace, including legislation.

The fourth type of risk is associated with the lack of adequate representation of personal opportunities to maintain their own health. Coordinated directly by man. It depends on the level of knowledge about the world and about yourself. In this regard, in the modern era of globalization, bridging the gap between scientific knowledge and its practical implementation has been declared one of the most important tasks of public health [6].

In accordance with the types of risks, their degree, potential danger is determined and technologies that save health are created. Attention in this article is aimed at minimizing the risks of the fourth type. Constant updating of technologies that preserve human health makes their analysis relevant.

\subsection{The problem of insufficient physical activity}

Let us dwell on the key issues related to the problem of insufficient physical activity and technologies of healthsaving behavior.

The health of different generations of people is directly related to their lifestyle. According to the World Health Organization, up to $50 \%$ falls on the elements of a healthy lifestyle, among which physical activity stands out. At the same time, there is an increasing concern in the global scientific community about the lack of physical activity. Publications in Lancet prove that physical inactivity is the cause of 5.3 million deaths per year worldwide. If inaction decreases by only $10 \%$, half a million deaths can be prevented each year [7].

Insufficient physical activity is considered as an important factor causing non-communicable diseases not only in high-income countries, but also in low- and middleincome countries [1]. Hallal PC Andersen LB Bull FC et al. indicate a limited level of physical activity. Based on the monitoring of physical activity with data for adults ( 15 years and older) from 122 countries of the world and for adolescents (13-15 years) from 105 countries, they concluded that "worldwide, $31.1 \%$ (95\% CI 30.9-31.2) adults are physically inactive, with their share ranging from $17.0 \%(16 \cdot 8-17 \cdot 2)$ in South-

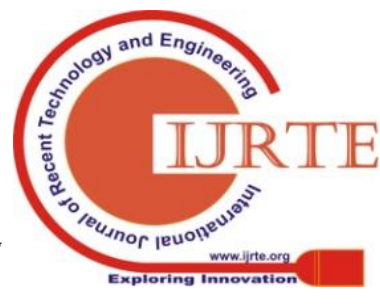


East Asia to about $43 \%$ in America and the Eastern Mediterranean. Inaction increases with age; higher for women than for men, and increases in high-income countries. The proportion of children aged 13-15 years who perform less than 60 minutes of moderate-to-high-intensity physical activity per day is $80.3 \%(80 \cdot 1-80 \cdot 5)$; boys are more active than girls" [3].

Reducing the level of physical activity affects primarily the indicators of overweight and obesity and, as a consequence, the occurrence of a number of diseases. Despite the fact that a healthy lifestyle is five times more effective than therapeutic and diagnostic procedures, and the ratio of expenses and income from the implementation of healthy lifestyle programs ranges from 1 to 8 [15], indicators of insufficient physical activity tend to increase in many countries. At the country level, there is a significant gap between adolescents and between men and women. Overweight among the population increased from $55.9 \%$ in 2010 to $58.7 \%$ in 2016, and obesity increased from $20.8 \%$ to $23.3 \%$. In most countries, indicators of overweight were higher in men, and obesity rates in women [16].

Data on the causes of physical activity and its connection with diseases allow you to create effective, healthimproving technologies.

\subsection{Health-saving technologies}

Health-saving technologies are prevention and protection technologies that ensure the psycho-physiological safety of a person. They embody strategies aimed at preserving and promoting health and developing a healthy lifestyle. Presented in medical, educational, political and humanitarian discourses. Are a condition for the development of self-regulation of personality.

Technologies that support a healthy lifestyle can be elements of ordinary, everyday human activity, as well as actions of public authorities and professional organizations. Implemented in the form of programs, strategies, projects.

Our monitoring has allowed us to identify promising health-saving technologies.

The benchmark for an effective health care system in the European community can be Germany. The example of this country's technology shows the result of the philosophy of prevention and protection. The state not only declares respect for its health, but also pursues a policy of action.

35 years ago, the Germans set a goal to improve the health of the nation, and for this all conditions were created: a lot of treadmills in various institutions; in the parks special runs for jogging, built pools, artificial lakes and other attributes of a healthy lifestyle. All this played the role of practical propaganda of physical activity and taking into account the impact on the health of nature. Later, new strategies emerged, and today we are witnessing their effective implementation. Modern sports fields and bike lanes, products with a full indication of the composition and caloric content, accessible centers for health improvement and disease prevention - such an understanding of a healthy lifestyle for people in Germany. Given the fact that the cost of treatment in the state occupies a large part of all budget expenditures, disease prevention measures are cheaper.

State policy is aimed at supporting people involved in sports, especially young people, they constantly carry out actions, even use monetary rewards for a healthy lifestyle. Some companies organize their corporate competition for employees. In schools, children are taught how to eat right and improve their health. The purpose of such technologies is to form the desire of the population to be healthy. The same policy is pursued by the United Kingdom, Finland, Japan, Canada, Australia and other highly developed countries.

Monitoring the implementation of policies for maintaining a healthy lifestyle (creating conditions for the widespread introduction into everyday life of various forms of physical activity in organic combination with a balanced diet, combating bad habits and improving the ecological environment) showed that Finland, Japan, Canada, Australia and other highly developed countries over the past $40-60$ years have achieved good results. The mortality rate of people of young and middle age has decreased several times, the average life expectancy has increased by $15-20$ years, and the viability of the population has sharply increased.

The positive dynamics of using technologies for the preservation and promotion of health in these countries orients their widespread use.

Over the past five years, most countries in the European Union, as well as the United States, Canada, Australia and Japan, have adopted national strategies and recommendations for the introduction of recreational motor activity for various population groups.

Ukraine has also made a bet on a healthy lifestyle. The National Strategy for the Improvement of Motor Activity in Ukraine for the period up to 2025 notes that in Ukraine in the $21 \mathrm{st}$ century there was no significant progress in attracting people to improve physical activity. The results of the all-Ukrainian survey show that at the beginning of the 21 st century, only $3 \%$ of the population aged 16 to 74 years had an adequate level of improvement in physical activity (at least 4-5 lessons per week for one lesson at least 30 minutes), the average level ( 2 - 3 classes per week) $-6 \%$, low level ( $1-2$ classes per week) $-33 \%$ of the population. Hypokinesia is characteristic of the majority of the adult population. Among children, the popularity of sedentary leisure is growing [10].

The imperfection of the health care system in Ukraine for a long time, the low level of awareness of the value of health as equity, the stay of the overwhelming majority of the population in conditions of socio-economic instability led to the creation of conditions unfavorable to a healthy lifestyle [10]. In this regard, the National Strategy for the Improvement of Motor Activity in Ukraine for the period up to 2025 notes "Motor Activity - Healthy Lifestyle - Healthy Nation" was adopted, and at the government level, an action plan until 2025 was developed and approved for implementation [12]. This plan provides for measures to promote healthy lifestyles from both the government and local authorities and public organizations. The target audience of the National Strategy is youth. In connection with this, a value attitude to their health is formed among young people and, in particular, in such groups as employees of the Armed Forces and other military formations, students, schoolchildren, employees of enterprises, institutions and organizations and children. Within the framework of this task, informational and preventive measures "Responsibility begins with me", "Sport for all", promotion of a healthy lifestyle through training, publicly available physical training and recreation and other forms are provided. Separately highlighted activities for children with 
disabilities. Despite the fact that the plan does not highlight quests, they are quite a popular form of advertising a healthy lifestyle.

It should be noted that, in terms of the National Strategy for the Improvement of Motor Activity [12], there is not a sufficient variety of projects targeting middle-aged and older groups. These shortcomings are solved by various public, professional and economic structures. Thus, a fairly innovative project to attract people to a healthy lifestyle based on advanced technologies was presented by Monobank, which offered its clients a deposit "Sporty". Its essence lies in the fact that the client needs to go through or complete 10,000 steps per day or more within three months, and then he will receive an additional $5 \%$ per annum at the standard rate. If the condition is not met for three or more days, and the client does not have 10,000 steps per day, the deposit rate will be reduced by the same $5 \%$ per annum. It is supposed to measure activity using Apple Health and Google Fit, as well as devices and applications that are synchronized with them: Mi Fit, Runkeper, Strava, Garmin and others. Monobank works under the slogan "A healthy lifestyle is impossible without movement!" and "Get a charge of cheerfulness and optimism!". For example, Monobank illustrates Hindu Fogju Singh, who covered a distance of $42 \mathrm{~km} 195$ meters at the age of 100 years and entered the Guinness Book of Records as the oldest marathon runner in the world [9].

The project "Creating shared values" established by the Swiss company Nestle S.A. deserves attention. in 2009. It was aimed primarily at promoting healthy nutrition and a healthy lifestyle, the development of agriculture and the conservation of water resources. The Nutritional Compass is not only a tool developed by Nestle that helps consumers choose foods and drinks based on the information on the package, but also lead a healthy lifestyle. In accordance with the recommendations of the company Nestle, "the energy that we get from food should be spent. Most of us are hostages of a sedentary lifestyle. And therefore, physical activity is of great importance not only for keeping fit, but also helps to relax after an emotionally intense day and is the prevention of certain diseases. Try to walk more, give up the elevator, go in for sports - it's better to have a little, but do it regularly! On average, the energy requirement of an adult is 2000-2500 kcal / day" [11]. As part of this program, Nestle collaborates with numerous government and international organizations whose activities are aimed at improving nutrition and public health, and supports various programs aimed at raising public awareness of the basics of proper nutrition, as well as fostering good eating habits in children. The goal of the Nestle Healthy Kids global program is to initiate the introduction of training programs aimed at developing a culture of healthy nutrition and healthy lifestyles in those countries where Nestle is focused. To date, projects with the support of Nestle are implemented in many countries, and the total number of children trained under such programs is 10 million.

As part of the global program "Healthy Children" in Ukraine, the "Abetka kharchuvannya" program was developed - this is a training course for students in grades 1 - 4. This program has become an integral part of the course "Fundamentals of Health" for secondary schools. The main goal of the program is to teach children the principles of proper nutrition and to inculcate in them the habit of sticking to these principles in everyday life. In the

long term, the program is aimed at shaping a personal need to lead a healthy lifestyle: eat right, maintain a balance of physical and psychological health [11].

Along with the topic of individual and public health, physical activity, one of the central places on the agenda of modern humanity is the problem of preserving the human personality, preserving the human being as a biosocial structure. This global problem is sometimes called the "modern anthropological crisis". In this regard, mental health promotion programs are highly relevant. Every fourth resident of the European Region at some point in their lives suffers a type of mental disorder. A particularly urgent, but difficult task is to improve the early diagnosis of depression and prevent suicide through interventions at the local community level. Research data provides a better understanding of the destructive connection between mental disorders and social marginalization, unemployment, homelessness, alcohol and other psychoactive substances. It is necessary to take into account new forms of psychological dependence associated with the proliferation of online forms of virtual reality.

We would like to draw your attention to the fact that modern telecommunication technologies, especially Internet technologies, do not always create a positive attitude in the positioning format of a healthy lifestyle. Guided by the priority of trade, but hiding behind the declaration of health, quite often use speech practices of direct and indirect effects on people, reducing all moral norms. Such speech formulas are used as "you don't need to worry about morality", "it's just your business" and such ones cause irreparable harm to the human psyche.

Thus, the topic of human health is of interest for further research and description.

\section{FINANCIAL DISCLOSURE}

The study found that health is defined as a starting point for human self-realization in the format of a philosophy of prevention and protection. The formation of a physically and psychologically healthy self-sufficient personality is associated with a healthy lifestyle. It is noted that a healthy lifestyle is associated with the strengthening and development of physical and mental health of the individual. Innovative technologies play a significant role in maintaining health. Priority is given to motor activity. Insufficient physical activity is considered as an important factor causing non-communicable diseases.

The factual material allows us to conclude that healthsaving technologies are prevention and protection technologies that ensure the psycho-physiological safety of a person. They embody strategies aimed at preserving and strengthening health, establishing a healthy lifestyle. Represented in medical, educational, political and humanitarian discourses. Are a condition for the development and self-regulation of the individual.

The data of the study showed that the formation of the requirements for maintaining a healthy lifestyle is an important social task of medicine, philosophy, sociology, pedagogy and other branches of human knowledge, each individually taken person and the whole society. In this connection, an integrated approach to its solution is required.

Published By: 


\section{REFERENCES}

1. Bauman, A. E., Ries, R/ S., Sallis, J. F., Wells, J. C., Loos, R. J., Martin, B. W., \& Lancet Physical Activity Series Working Group. (2012). Correlates of physical activity: why are some people physically active and others not? The Lancet, 380(9838), 258-271.

2. Gnatik, Ye. N. (2008). Problemy tsennosti zhizni i zdorov'ya cheloveka $\mathrm{v}$ svete perspektiv geneticheskoy inzhenerii. Filosofiya nauki tekhniki. 1. [In Russian]

3. Hallal, P. C., Andersen, L. B., Bull, F. C., Guthold, R., Haskell, W., Ekelund, U., \& Lancet Physical Activity Series Working Group. (2012). Global physical activity levels: surveillance progress, pitfalls, and prospects. The lancet, 380(9838), 247-257.

4. Hallal, P. C., Martins, R. C., \& Ramírez, A. (2014). The Lancet physical activity observatory: promoting physical activity worldwide. The Lancet, 384(9942), 471-472.

5. Informatsionno-analiticheskiy sayt Khvilya. URL: https://hvylya.net/analytics/society/evroreformirovanie-ukrainyitsennosti-imeyut-znachenie.html [In Russian].

6. Lapaige, V. (2009). Evidence-based decision-making within the context of globalization: A "Why-What-How" for leaders and managers of health care organizations. Risk management and healthcare policy, 2, 35.

7. Lee, I. M., Shiroma, E. J., Lobelo, F., Puska, P., Blair, S. N. Katzmarzyk, P. T., \& Lancet Physical Activity Series Working Group. (2012). Effect of physical inactivity on major non-communicable diseases worldwide: an analysis of burden of disease and life expectancy. The lancet, 380(9838), 219-229.

8. Maslow, A. H. (1970). Motivation and Personality New York. NY: Harper \& Row. URL: http://www.peyc.eu/wpcontent/uploads/2016/09/Motivation-and-Personality-A.H.Maslow.pdf

9. Monobank URL: http://monobank.biz/2018/09/26/depozit-sportivnyjv-monobanke [In Russian].

10. Natsional'na stratehiya $\mathrm{Z}$ ozdorovchoyi rukhovoyi aktyvnosti Ukrayini na period do 2025 roku "Rukhova aktyvnist' - zdorovyy sposib zhyttya - zdorova natsiya" 42/2016 vid 09.02.2016 URL: https://zakon.rada.gov.ua/laws/show/42/2016\#n14 [In Ukrainian].

11. Nestle. URL: https://www.nestle.ua/nutrition/healthy-rules/move [In Ukrainian].

12. Plan zakhodiv shchodo realizatsiyi Natsional'noyi stratehiyi z ozdorovchoyi rukhovoyi aktyvnosti v Ukrayini na period do 2025 roku "Rukhova aktyvnist' - zdorovyy sposib zhyttya - zdorova natsiya" na 2019 rik 541-2018-r vid 26.07.2018 URL: https://zakon.rada.gov.ua/laws/show/541

13. Vetkov, N. Ye. (2016). Zdorov'ye cheloveka kak tsennost' i yego opredelyayushchiye faktory. Nauka-2020, (5 (11)). URL: https://cyberleninka.ru/article/n/zdorovie-cheloveka-kak-tsennost-iego-opredelyayuschie-faktory [In Russian].

14. World Health Organization website. Constitution (Constitution) of the World Health Organization URL: https://www.who.int/governance/eb/who_constitution_ru.pdf

15. World Health Organization website. Constitution (Constitution) of the World Health Organization URL: https://www.who.int/governance/eb/who_constitution_ru.pdf

16. World Health Organization website. (2018). The European health report 2018.2 URL: http://www.euro.who.int/_data/assets/pdf_file/0006/380481/HEALT H_REPORT_HIGHLIGHTS_2018_RU.PDF?ua=1

\section{AUTHORS PROFILE}

Varynskyi Vladyslav Candidate of Political Sciences, lecturer, Odessa State University of Internal Affairs, Uspenska st. 1, Odessa, Ukraine, 65014

*Corresponding author: Email: vlad.varinskiy@gmail.com 